\title{
SIX SIGMA AND SIX SIGMA SYSTEM IN THE FUNCTION OF QUALITY AND PROFITS INCREASE
}

UDC: 330.143

Review Paper

\author{
Branko POPOVIĆ ${ }^{1}$, Ljiljana Z. MILETIĆ ${ }^{2}$ \\ ${ }^{1}$ University of Belgrade, Mechanical Faculty, 11000 Belgrade, Kraljice Marije 16, Republic of Serbia \\ ${ }^{2}$ EDUCONS University, Faculty of Project and Innovation Management, Bože Jankovića 14, 11010 Belgrade, \\ Republic of Serbia \\ E-mail: 1jmilet1@gmali.com
}

Paper received: 30.11.2016.; Paper accepted: 08.12.2016.

\begin{abstract}
Quality is the degree to which a set of permanent characteristics fulfills default, set, contracted or planned requirements for the result of the process (semi-finished product, product, documentation, services). There is a widespread belief in America that the quality is always determined by the user, not the supplier, because the quality is important not only because of the cost but because there is a completely different approach to maintaining the quality of the process. In Serbia, the applicable ISO 9000 family of standards which demonstrates the ability of suppliers, allows only stabilization of the current level of quality but not its increase that can be achieved only through better design and application of new materials and technologies. Application of Six Sigma is a different approach, which actually increases the level of quality and organization's profit; using modern computer technology it also allows the reduction of defects in the process, until the defects of 3.4 per million are realized as the results of the process. Since in Serbia, it is difficult to achieve, the authors have developed a special system of Six Sigma System, which allows realisation of a number of projects for reduction of possible costs, shortening time rational, radical elimination of losses, significante increase of the quality of the process and increase of organizations' profit.
\end{abstract}

Keywords: Quality Control, Six Sigma, Six Sigma System.

\section{INTRODUCTION}

For any business enterprise it is important to achieve business excellence, which is based on meeting customers' demands, improving the bussines productivity and corporative social responsibility (Ćoćkalo et al., 2015) as well as keeping high and consistent level of quality. There are many models of advanced systems: ISO 9001, Malcolm Baldrige Award, Continuous Improvement/Quality Management (QI/QM). Six Sigma is buseness model, which is oriented towards quality and profits, and whose application has become actual in Serbia. That model is based on significant theoretical discoveries in mathematics, probability, statistics (Juran, 1992; Quinn, 1996; Summers, 2000), and organizational management, as obtained in the previous period, as well as on practical achievements on the basis of the application of the family of international standards ISO 9000, quality management model ISO 9001 and model for assessing the excellence of organization and determination of losses due to defects (Popović et al., 2008; Popović and Ivanović, 2011; Bošković and Popović, 2014; Милетич et al., 2015; Popović and Nikodijević, 2015). Recently, many important theoretical discoveries have been developed in the fields of organizational management, which can be treated through four stages of development organizations and which formed the basis for the development of Six Sigma. In the second stage of mechanical development, a special contribution was given by W. A. Shewhart (1891-1967) due to his theoretical and practical works while allocating the two types of sources of process variation (controlled variations that require modification of process elements and uncontrolled variations), introducing control charts to manage the process stability and methodology of PDCA for organization's process 
and business management (Popović and Todorović, 1998; Popović, 2016). In fourth (integrative) and fifth (system) final stage of organization development many practical achievements aimed for the more efficient organization's businesss management and improvement of quality of the process results were done.

Special contribution was given by W. E. Deming (1900-1993), who is particularly responsible for identification of typical process variation, (systemic - caused by employees errors and accidental - caused by the irresponsible behaviour of employees), practical application of Shewhart's concept of statistical process control and improving the quality and competitiveness of organization with a reference to organization management on seven "obstacles" and the need for application of 14 well-known obligations, which are also partly involved in the ISO 9000 family of standards (Popović and Todorović, 1998; Popović, 2016). In addition, J. M. Juran (1904-2008) on the basis of his practical work in the United States and Japan contributed significantly to the development of the current concept of quality management and organization business while defining the "quality trilogy" (Planning the required quality; Controlling the realized quality and Improving the established quality), which is also partly included in the ISO 9000 family of standards, stipulated the need for six phases of quality planning, phases of quality testing and recommended eight stages for transition of organization to a higher level of business (Juran, 1992; Popović, 2016). Thus, the merits of T. Ohno (1912-1990) should be also added; he advocated for the Lean manifacture, JIT, Kanban approach to the business market and elimination of losses; as well as of S. Shingo (1909-1990), who advocated for Poka-Joke production without defects and SMED manufacturing processes with rapid process changes in less than a minute Ohno, 1988; Popović, 2016.

The development of modern concept of organization management was also supported by the works of K. Ishikawa (1915-1989), based on the Cause - and - Effect - diagram and initiation of the Quality Circles (Ishikawa, 1985; Popović, 2016), The A. V. Feigenbaum's (1920-2014) concept of general quality management and P. Crosby's "14 steps, 4 absolutisms and 6 supplements" which he recommended aiming for realization of practical contributions to improving the quality, quality management and training personnel for quality (Popović, 2016). Going one step further, G. Taguchi (1924-2012) with his work in Japan, performed a step forward in organization management by his Core Projects for Business Management (system design, parameter design and tolerance design) (Taguchi, 1986; Popović, 2016). M. Imai (1930-) contributed to the practical application of process improvement with the Kaizen system with the following possible approaches: elimination of losses, "5 S" analysis for improving the process efficiency and implementation of standardized working procedures, as well as by definining "golden rules" for locating the difficulties in quality achievement (Imai, 1987; Popović, 2016). Discoveries to the emergence of Six Sigma (1986) was influenced by the issuance of the first standards of quality: 1959 (MIL-Q-9858), 1974 (BS 5179) and preparation of standards in 1987 (ISO 9000), in international organization ISO. The US in 1987 (Baldrige) was also influential as well as the European model of 1988 (EFQM) for assessing the excellence of organizations, along with the models for determining losses due to defects which mainly include models of losses by: costs (Prevention, Appraisal and Failure model, PAF), processes (Cost of conformance, COC) and the causes of errors (Kano, 1984; Miletić et al., 2005; Popović i Bošković, 2011; Popović et al., 2014). Although these findings are based on scientific principles, they are exact and proved it, but unfortunately, have not so far been widely used in practice. It was not an appropriate practical approach since the organizations have lacked the necessary basic mathematical skills, delayed the introduction of computers in practical application and also there were great resistance in organizations.

Nowadays it has changed since the Six Sigma methodology has included most of these discoveries, and successfully proved possible application and achieved an increase in profits in major US organizations: Motorola, Toyota, Ford Motor, Chrysler, General Motors, Boeing (Harry and Schroeder, 2000). It is believed that Six Sigma, surpassed the previous advanced systems: ISO 9001 (ISO, 2015), Malcolm Baldrige Award, Continuous Improvement/Quality Management (QI/QM). Although, on the basis for defining quality, Six Sigma (defects per milion opportunities) in comparison with ISO 9000 (features and characteristics of product or service), Baldrige Award (Customer driven) and CI/QM (Customer driven) enables significantly more 
efficient operation of organization, it is considered more suitable for applications in large organizations, with more than 500 workers. Therefore, for application in Serbia, a smaller Six Sigma system was developed, which is favoured by smaller organizations with 200-400 employees (Popović and Klarin, 2002; Popović et al., 2008; Popović and Ivanović, 2011; Popović and Nikodijević, 2015; Miletić et al., 2016; Popović, 2016).

\section{SIX SIGMA}

Six Sigma is a set of techniques and tools used to improve the process, at the advanced level of knowledge in mathematics, probability, statistics and organization management. Six Sigma improves organization's operations reducing the deviations in processes, possible costs, shortening time rational, radical elimination of losses, significantly increases the quality of the process and increases organizations' profit, (De Feo and Barnard, 2005; George et al., 2005). "System Six Sigma" was created in 1986 in Motorola, by engineer William B. Smith, Jr. (1929-1993), "Father of Six Sigma," is director John F. Mitchell and company president Bob Galvin's (Pyzdek, 2003; Stamatis, 2003; Truscott, 2003).

\section{Controlling process}

Controlling the realization of the process is the only way to determine the quality of the results of the process (semi-products, products, documentation and services). Controlling process includes checking the input characteristics, current implementation and output characteristics of realized results of the process. The input characteristics of the process include the available data and expected results of process (quantity, quality) characteristic (Popović, 1993; Popović and Todorović, 2000).

Flow characteristics embodiments are precision indicis $(P C I)$ and accuracy $(P P I)$, as well as stability of the process. Indices of precision and accuracy of defining the middle position $(\mu)$ in relation to the tolerance $(T)$ meet the following criteria: insufficient $(P C I \leq 1)$, sufficient $(I<P C I \leq 1.33)$ and good $(P C I>1.33)$ precision, or insufficient $(P P I \leq 1)$, sufficient $(1<P P I \leq 1,33)$ and good (PPI>1.33) accuracy. Process stability depends on the position of the displayed values on the control chart, as compared to control limits $(L T L, U T L)$ and the central line $(\bar{x}, \bar{R})$, wherein the condition is determined by the stability of eight typical instability (ISO, 2012). The output characteristics of the process include the size of a small sample, taken from a larger set (series) of the process.

The characteristics of the process include measured or controlled sample size and known or estimated size set (series). The sample sizes in the process are: variable size $(x)$, lower and upper limits $(d g$, $g g$ ), the mean (arithmetic mean) value $(\bar{x})$, median $\left(\eta^{\prime}\right)$, range $(r)$ and standard deviation $(s)$. Sizes of set in the process are: variable size $(X)$, lower and upper limits $(L T L, U T L)$, tolerance $(T=U T L-L T L)$, mean $(\mu)$, median $(\eta)$, range $(R)$, standard deviation $(\sigma)$, width $(W= \pm 3 \sigma)$, probability of confidence $(P)$ and probability of risk $(Q=1-P)$ conducted inspection. In controlling, implementation process need to examine static and dynamic processes.

\section{Static and dynamic processes}

Controlling static process defined output characteristics of the process, showing the law of normal distribution value variable $(X)$, width $(W= \pm 3 \sigma)$ and the calculated or estimated sizes $(\mu, x)$. Features of the process are: the average $(\mu)$, standard deviation $(\sigma)$, process tolerance $(T)$, precision index (process capability indices, $P C I$ ), accuracy of the index (process performance indices, $P P I)$ and the stability of the process $(\mathrm{X}$, EWMA, R, $\bar{x}$, s-charts). Static process has a width of realization $(\mathrm{W}=W= \pm 3 \sigma)$ ) with mean $(\mu)$, which is always located symmetrically within the tolerance $(T=L T L-U T L)$, as shown in Figure 1 (Popović, 1990).

William Smith in his long practice in quality management has studied static processes in Motorola and made the following two conclusions:

1. The first production of electronic products, with 2700 failure of a million of realized products does not give an acceptable quality that requires high precision and accuracy of the result of the process,

2. The second implementation of the process is not static but dynamic changes over time; instead of controlling the unreal (virtual) static process it should be applied in controlling the actual (real) dynamic processes, which will enable the achievement of higher levels of quality. 
As each process has a certain constant realized width $(W= \pm 3 \sigma)$, which moves over time within a tolerance $(T=U T L-L T L)$ symmetrically on both sides of the middle of the process $(\mu)$, there should be determined the optimal value of the dynamic displacement process $\pm 1,5 \sigma$, which will provide an acceptable level of quality of the results process. Hence, dynamic processes due to a shift of the process must have an even greater tolerance than static processes (ISO, 2015).
Conducted studies have included static control product quality and process stability over controll $\mathrm{X}$-cards, with the usual sample sizes: $n_{1}=$ $3, n_{2}=4, n_{3}=5$. After testing hypotheses, obtained results are shown in Figure 2, with volume curves test, or probability of failure $(P)$ in a particular shift process and sample sizes $(n)$. According to the diagram the value of suitable dynamic movement processes are in the area of $1,34 \sigma$ to $1,73 \sigma$, with an acceptable probability of failure of $P=0.5$.

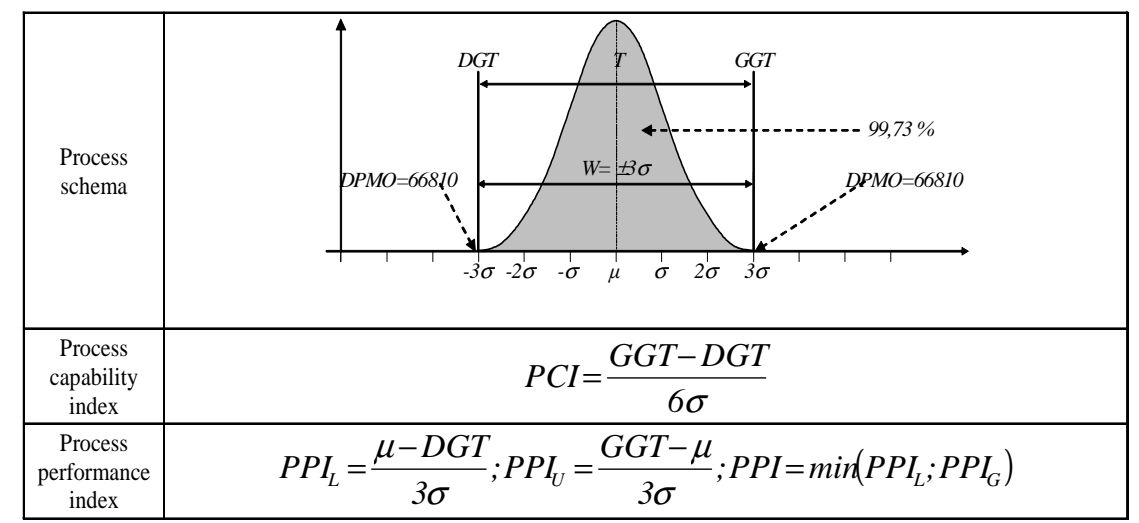

Figure 1: The static process with a tolerance $T= \pm 3 \sigma i \mathrm{DPMO}=2700$

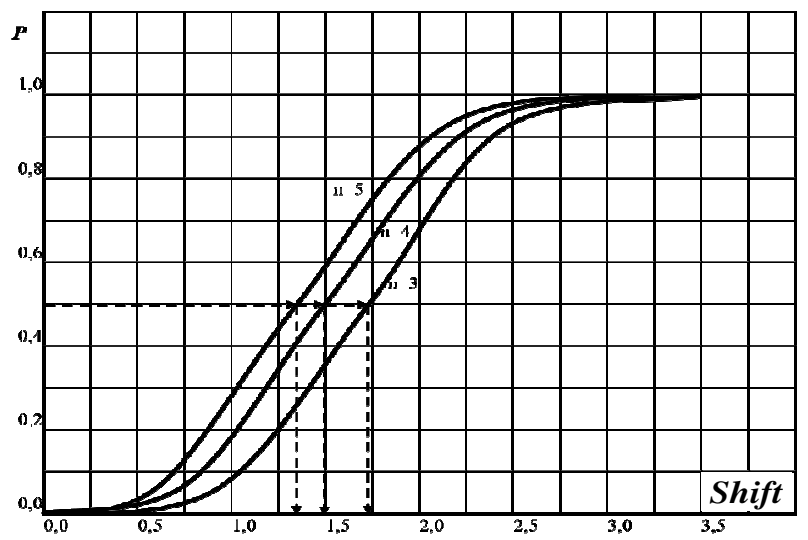

Figure 2: Power curves for hipothesis of shift process

William Smith has suggested that the dynamic process should adopt a rounded value of dynamic displacement processes $\pm 1,5 \sigma$ in relation to the environment of tolerance, which includes the sample size $n_{2}=4$ to control $\bar{x}$-chart. Determination of the required tolerance of dynamic process depends on the desired level of quality of the results process.

\section{Grade of quality}

Dynamic processes with a tolerance $(T= \pm 3 \sigma)$, dynamic shift $\pm 1,5 \sigma$ and critical shift $\Delta=1,5 \sigma$ give poor quality of the process, with unfavourable indices of precision $(P C I=1)$ and accuracy of the process $(P P I=0,5)$ with a number of faults $D P M O=66810$, as shown in Figure 3. These processes are acceptable only in semi (castings, forgings, pressings), whose failure caused fewer losses. Thus, static processes with a tolerance $(T= \pm 3 \sigma)$ and small defective $D P M O=2700$ show a false state of the process, that during dynamic 
implementation creates a far greater fault of $D P M O=66810$.

However, dynamic processes with a tolerance $(T= \pm 4 \sigma$ ), dynamic shift $\pm 1,5 \sigma$ and critical shift $\Delta=2,5 \sigma$ provide a higher quality of process, but with better accuracy indices $(P C I=1.33)$ and accuracy $(P P I=0.83)$ and with fewer defects $D P M O=6210$ according to the example shown in Figure 4, These processes are acceptable in: simpler products (shafts, gears), documentation (books, studies) and services (repair, maintenance) whose failure causes greater loss.

Dynamic processes with a tolerance $(T= \pm 5 \sigma)$, dynamic shift $\pm 1,5 \sigma$ and critical shift $\Delta=3,5 \sigma$ provide high quality results of the process, with more favourable indices of precision $(P C I=1.33)$ and accuracy of the process $(P P I=1.17)$ and even smaller number of defects $D P M O=233$, as shown in Figure 5.

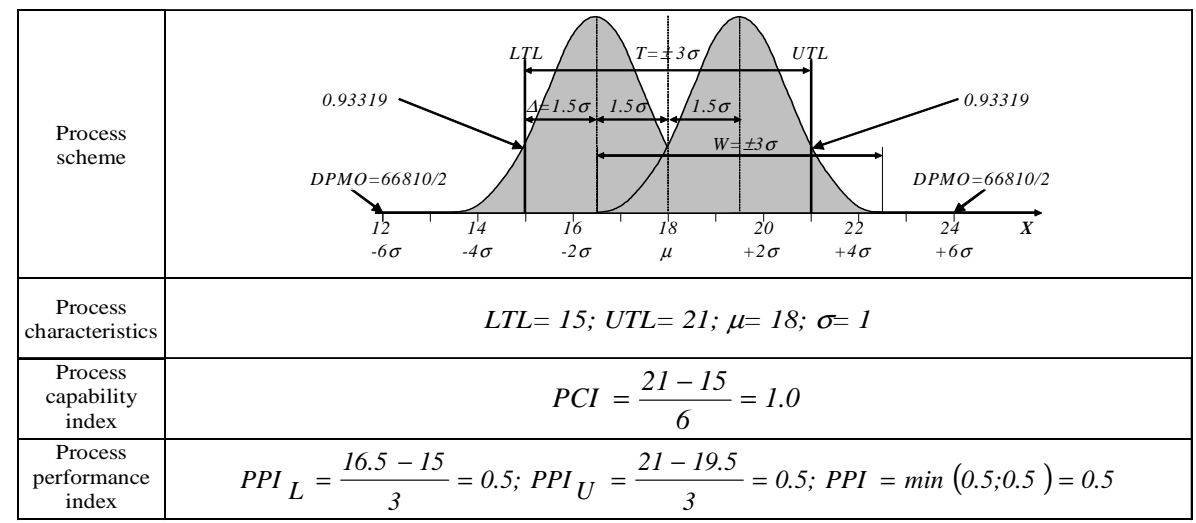

Figure 3: An example of a dynamic process with $T= \pm 3 \sigma i \mathrm{DPMO}=66810$

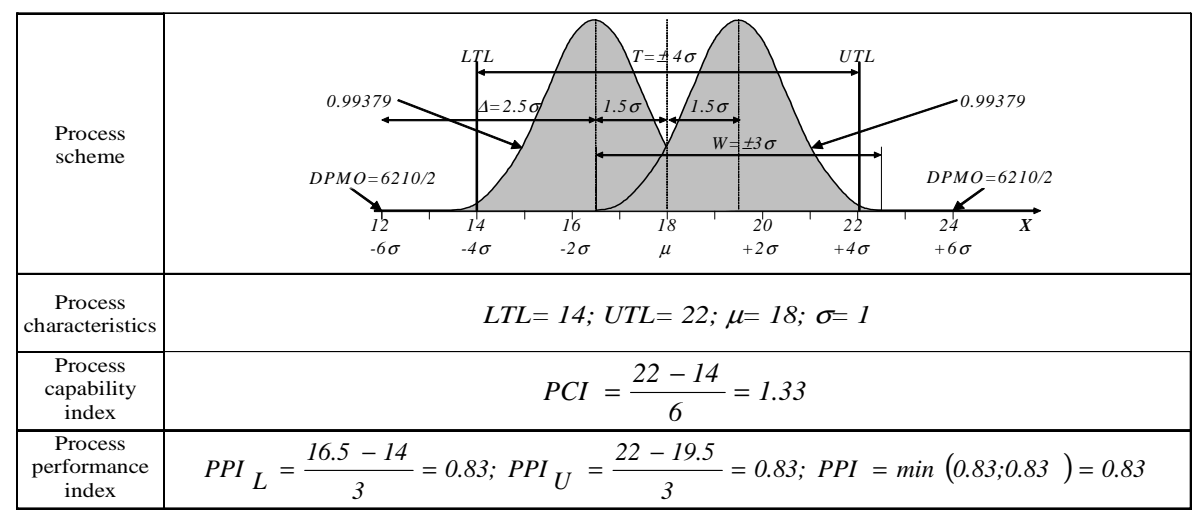

Figure 4: An example of a dynamic process with $T= \pm 4 \sigma i D P M O=6210$

\begin{tabular}{|c|c|c|c|}
\hline $\begin{array}{c}\text { Process } \\
\text { scheme }\end{array}$ & $L T L=13 ; U T L=23 ; \mu=18 ; \sigma=1$ \\
\hline $\begin{array}{c}\text { Process } \\
\text { characteristics }\end{array}$ & $P C I=\frac{23-13}{6}=1,67$ \\
\hline $\begin{array}{c}\text { Process } \\
\text { capability } \\
\text { index }\end{array}$ & \\
\hline $\begin{array}{c}\text { Process } \\
\text { performance } \\
\text { index }\end{array}$ & $P P I L=\frac{16.5-13}{3}=1.17 ; P P I$ \\
\hline
\end{tabular}

Figure 5: An example of a dynamic process with $T= \pm 5 \sigma$ and $D P M O=233$

Such processes are acceptable in complex: (calculations, reports) and services (postal and products (appliances, motors), documentation energy services) whose failure caused great losses. 
Finally, dynamic processes with a tolerance $(T= \pm 6 \sigma)$, dynamic shift $\pm 1,5 \sigma$ and critical shift $\Delta=4,5 \sigma$ provide the highest quality of the process, with the best indices of precision $(P C I=2.0)$ and accuracy of the process $(P P I=1.5)$ and with the lowest number of defects $D P M O=3.4$ as shown in Figure 6. These processes are acceptable to the most complex: product (ships, aircraft), documentation (projects, software) and services (air transport, hospital services), whose malfunction caused the greatest losses.

Using these examples may be divided into certain class of quality depending on the applied size tolerances according to Table 1.

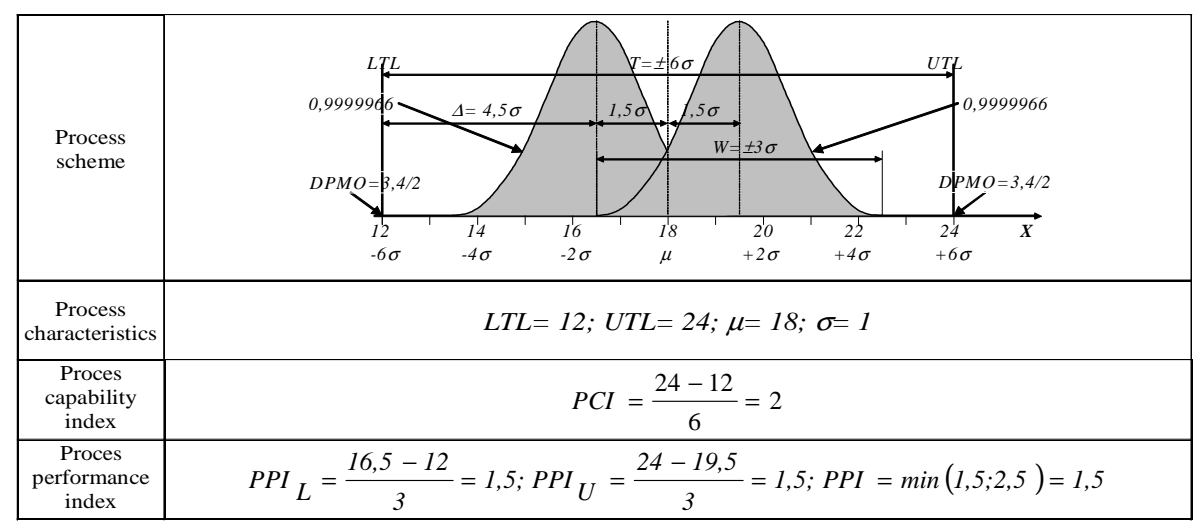

Figure 6: An example of a dynamic process with $T= \pm 6 \sigma$ and $D P M O=3,4$

Table 1: Class quality of the products and their characteristics

\begin{tabular}{|c|c|c|c|c|c|c|c|}
\hline $\begin{array}{c}\text { Class } \\
\text { quality }\end{array}$ & $\begin{array}{c}\text { Tolerance } \\
\boldsymbol{T}\end{array}$ & $\begin{array}{c}\text { Critical } \\
\text { shift } \\
\boldsymbol{\Delta}\end{array}$ & $\begin{array}{c}\text { Capability } \\
\text { Index } \\
\boldsymbol{P C I}\end{array}$ & $\begin{array}{c}\text { Performance } \\
\text { Index } \\
\boldsymbol{P P I}\end{array}$ & $\begin{array}{c}\text { Nondefective } \\
\text { probability } \\
\boldsymbol{\Theta}(\boldsymbol{x})\end{array}$ & $\begin{array}{c}\text { Defective } \\
\text { probability } \\
\tau=1-\boldsymbol{\Theta}(\boldsymbol{x})\end{array}$ & DPMO $\tau$ \\
\hline Classical & $\pm 3 \sigma$ & $1.5 \sigma$ & 1.00 & 0.50 & 0.93319 & 0.0668100 & 66810 \\
\hline Median & $\pm 4 \sigma$ & $.5 \sigma$ & 1.33 & 0.83 & 0.99379 & 0.0062100 & 6210 \\
\hline High & $\pm 5 \sigma$ & $3.5 \sigma$ & 1.67 & 1.17 & 0.999767 & 0.0002330 & 233 \\
\hline World & $\pm 6 \sigma$ & $4.5 \sigma$ & 2.00 & 1.5 & 0.9999966 & 0.0000034 & 3.4 \\
\hline
\end{tabular}

It can be seen that the world class quality, although very challenging, is indeed necessary, because only one at the same time provides good accuracy (PCI $=2$ ) and excellent accuracy of the process $(P P I=1.5)$.

\section{SIX SIGMA SYSTEM}

Six Sigma System is a set of techniques and tools for process improvement Six Sigma, with an advanced level of knowledge in mathematics, probability, statistics and organization management, which is limited to the performance of short-term projects. Six Sigma System can improve organization's operations by reducing deviations in processes, possible costs, shortening time rational, radical elimination of losses, significantly increasing the quality of the process and organization's profit, but it is not aimed at achieving world-class quality with $D P M O=3.4$ (Taguchi, 1986).
Although Six Sigma was introduced in America 30 years ago, it proved to insure the achievement of world-class quality with $D P M O=3.4$ a tall order. Only a few organizations have reached this goal; those who have reached it find difficult to maintain the results and most of the others are still struggling to catch up. Therefore, we think, in Serbia, Six Sigma System can be only launched and implemented, which will enable significant improvement in organization.

\section{System of organization}

Production organization in the implementation of process results establishes a large number of relationships with different stakeholders, and therefore its competitive ability will depend on the structure of internal and external quality chains (Oakland, 2003). The complexity of the chain of quality that is generated in processes of mutual relations of production organization of supplier (ISP) with the organization of user (KOR), provide three levels of formation of quality of process 
results: 1 . Phase qualities; 2. Basic qualities and 3. The overall quality of process results (Popović and Miletić, 2015; Miletić et al., 2016). System of organization in its organizational structure contains a number of smaller sub-systems of their infrastructure, which in addition to subsystem user KOR usually include the following group of 16 sub-systems and their 41 main processes, as shown in Figure 7: IST, research of market demand for the results of the process, RUK, management organization, $P R J$, design or creation and development of the process, PLA, planning and preparing implementation of the process, $U P R$, quality management of the process, $Z O K$, recruitment and training personnel of economic system, $N A B$, purchase of materials and equipment for implementation, $K O N$, input, process and output quality controlled, $O B E$, quality assurance of the process, REA, realizing technology of the process, $M A G$, storing products in warehouses, $P R O$, sales and distribution of the process, $U G R$, installation and installation of process for user, $S E R$, servicing or maintenance of the process, $F R P$, financial and accounting operations in economic system and OIM, security of property of the organization.

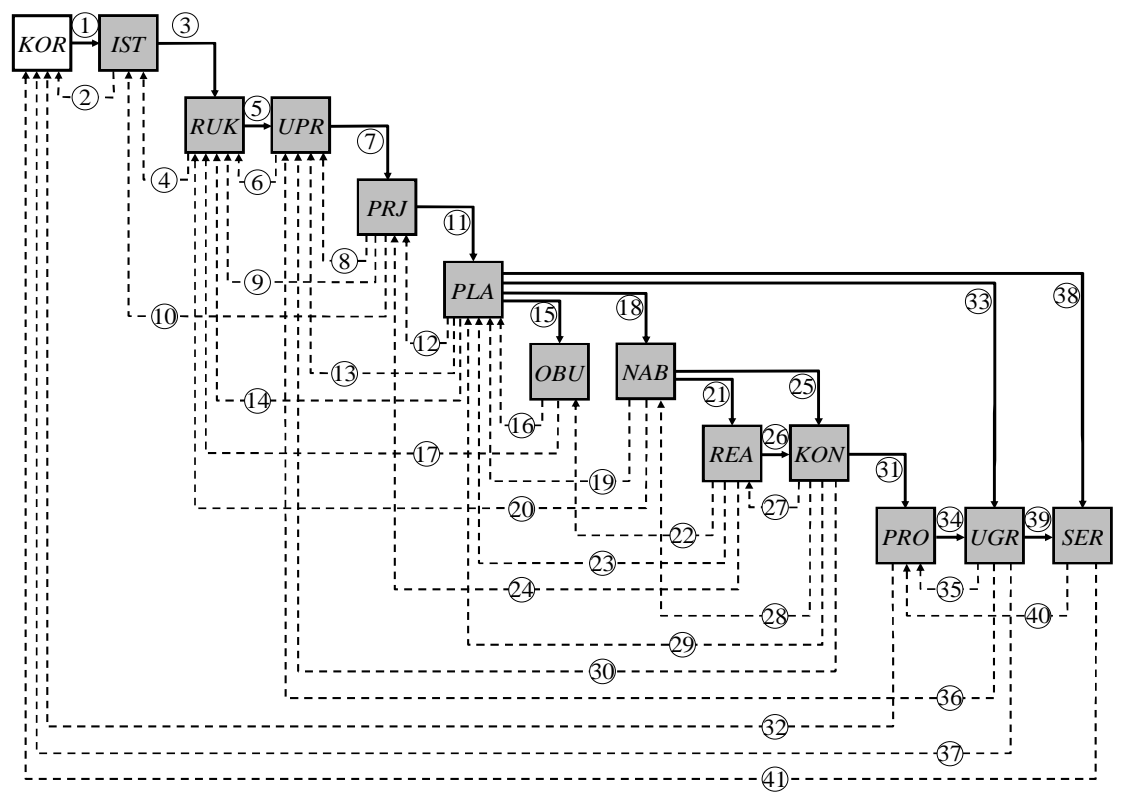

Figure 7: The system of organization with 16 most common subsystem (Popović et al., 2003; Miletić et al., 2016)

Each of these subsystems has its own processes, which can be business and technology, and production that generate production and service that generate services. Business processes are activities in implementation of management or administration (eg. REA, UGR) in organization. Production processes are activities in the development of intermediate products or documentation (eg. Processes: REA, UGR) in the organization. The service processes are the activities of providing service activities (eg. processes: IST, PRJ, PLA, ZOK, NAB, KON, OBE, $M A G, P R O, S E R, F R P, O I M)$ in organization (Popović and Klarin, 2003).

\section{Basics of Six Sigma System}

Searching for a more complete system of quality management which would help to improve business development of organizations in Serbia, the authors point out the main advantages of that system (Милетич et al.; 2015). Planned Six Sigma System allows realization of current implementation of short-term projects, solving vital problems of organization, operation formed working groups, and it is based on possible entrance system, necessary management system, necessary mechanism of functioning of the system and expected outputs of the system according to the scheme IDEF0 in Figure 8 (Popović, 2016a). At the entrance to Six Sigma System there are vital problems existing in the organization, the processes of Marketing subsystem (eg, excess costs), management (eg, slow decision-making), design (eg. poor quality), realization (eg. a large number of operating cycles and operations) and service (eg. small reliability) of the products. System management is accomplished through a manual prepared for each type of process. Manuals contain 5 defined control functions (forecasting, 
planning, organizing, coordinating and checking), 5 programs of action in the individual processes (MFSS, LFSS, DFSS, PFSS, SFSS), 5 consecutive stages of realization of projects (DMADC, DMAI, DMADV, DMAIC, DMAIV) and 5 various applicable procedures (essential and auxiliary, logic, arithmetic and computer), with instructions for using computer programs (MAT-LAB, RiskAMP- Excel, Minitab, Crystal Ball (ISO, 2011; ISO, 2011a).

The functioning of the system allows mechanism of separate funds for the costs of operating personnel Six Sigma System, the costs of consultants, training costs of the working groups and possible costs of further improvement of organization's operations. At the exit of the Six Sigma System there are expected results in Marketing (only necessary costs), management (faster decision making), design (sufficient quality), realization (less number of operating cycles and operations) and service (better reliability) of the products. Figure 9 shows the flow of the planned application of Six Sigma system which allows realization of short-term projects solving vital problems of the organization.

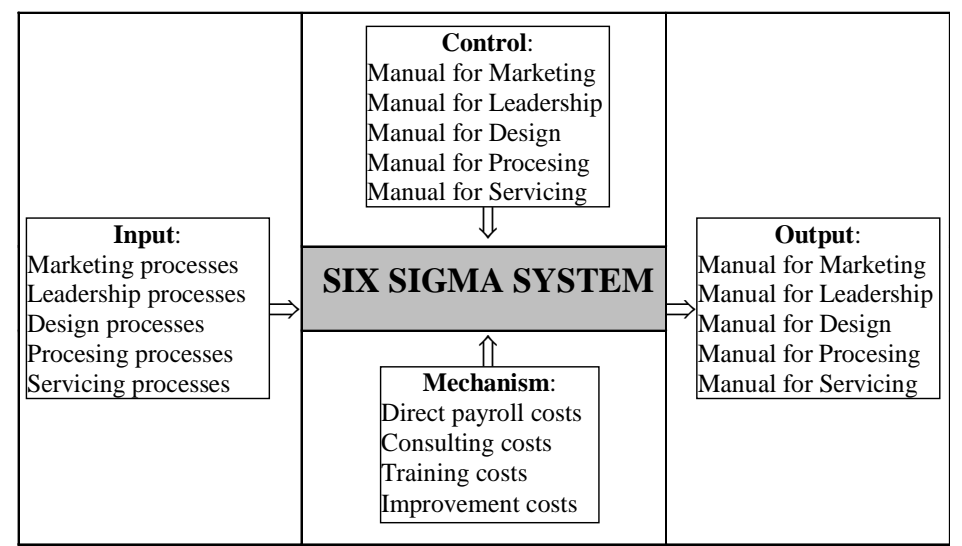

Figure 8: Scheme IDEFO Six Sigma System

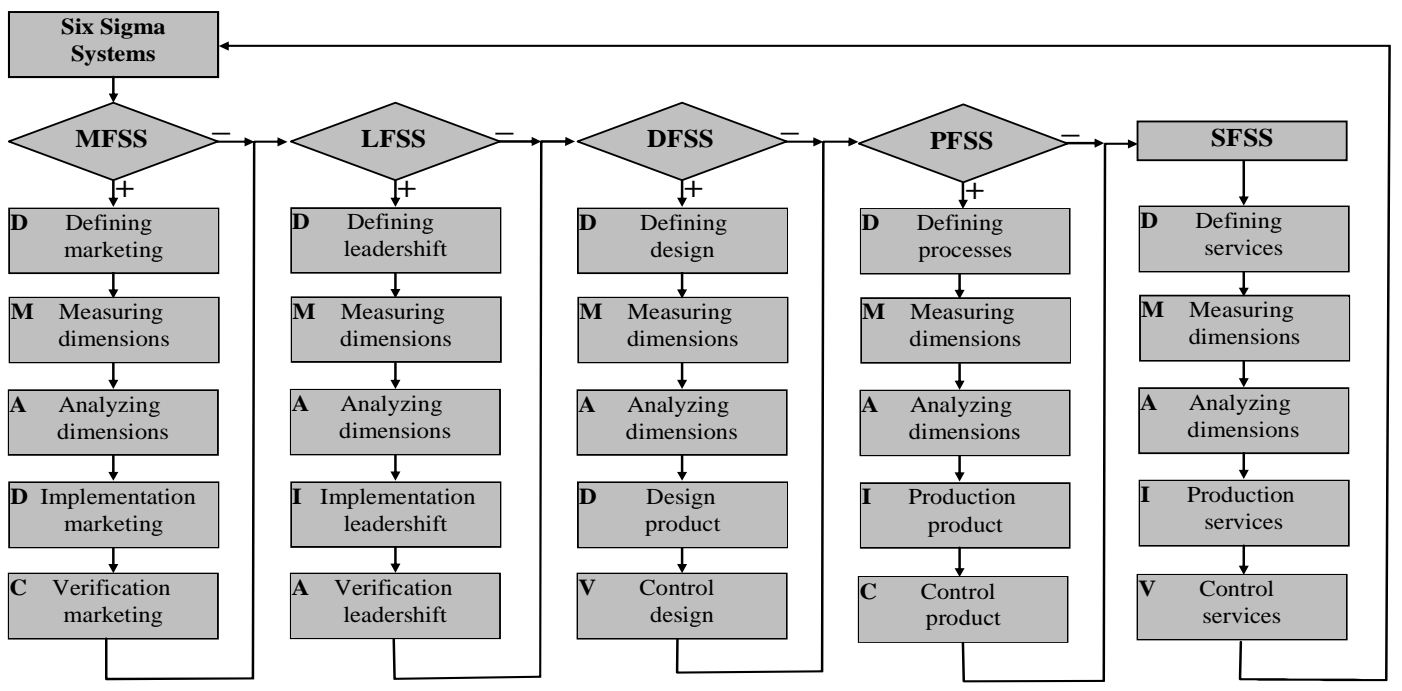

Figure 9: The flow of application plann of Six Sigma

Short-term applications of the process subsystem project are usual in Marketing and then, if necessary another application of the project is done, although two or more programs can be administered at the same time in the logical order.

\section{Programs Six Sigma System}

By considering such system organization and its main process, we noticed that there is a need to improve the next programme with the following ones, as shown in Figure 10: program of research needs (Manager Six Sigma system, MFSS), program management organization (Leadershift Six Sigma system, LFSS), program design 
products (Design Six Sigma system, DFSS), realization of products (Processes Six Sigma

system, PFSS) and program service product (Service Six Sigma system, SFSS).

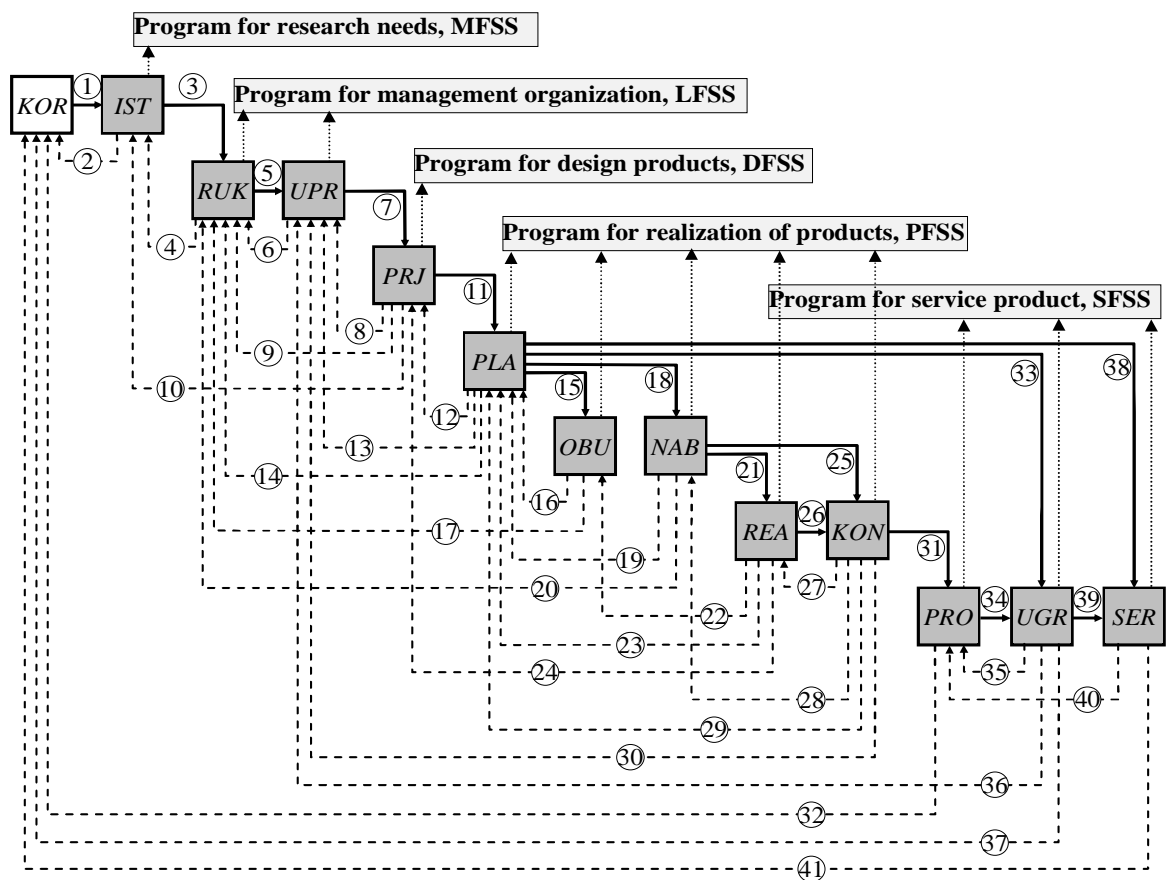

Figure 10: Required Programs Six Sigma System in system organization (Popović and Klarin, 2007)

\section{Application of Six Sigma System}

Application of Six Sigma System starts from the introduction which is schematically shown in Figure 11, with three phases of seven modules. The first initial phase information of the owner needs introduction of Six Sigma System, with modules A and B. Module A includes informing the owner of the selected program, necessary stages of the program and implementation of necessary procedures, during one day for about 20 participants, with determination of the leaders of the system (Black Belt). Module B contains information instructors and inspectors, on the need for the introduction of Six Sigma system, in one day, for about 17 participants. Next stage of introduction is formation of working groups, training participants for the selected program, stages and implementation of procedures, modules $\mathrm{C}, \mathrm{D}$ and $\mathrm{E}$.

The module $\mathrm{C}$ includes practicing instructors (Black Belt) for implementation of program, stages and procedures necessary for 2 days for 3 participants. Module D includes preparing inspectors (Green Belt) with instructors (1 group with 15 participants), selection and planning of initial project (6 day break after $3 \times 2$ time) and carrying out a project with working group $(4 \div 6$ weeks per project). Model E allows formation of working groups by the leaders of the system (Black Belt) for 1 day. The working group (working group) is a form of formal organizations, joint work of staff personnel, which connects the mission, goals, objectives, and common interest to improve organization's operations.

The third phase monitors and reviews the performance of the project, with modules $\mathrm{F}$ and $\mathrm{G}$. $\mathrm{F}$ module includes monitoring the project by the instructor and the leaders of the system (if necessary). Module $G$ contains a review of the performance of completed project, in terms of effectiveness and efficiency. If after considering the confirmation of the success of a project, it should be performed, it is done by motivating instructors and inspectors bonuses, who have contributed to this success. If after consideration the success of completed project is confirmed then planning and preparation of the same project should be repeated.

The fourth final phase allows preparation of a new follow-up project, which can also contribute to further improvement of business organization. Preparing necessary staff for introduction of Six Sigma system, with 5 programmes, 6 planning stages and a variety of application procedures, 
includes selection of suitable personality, and activities of selected personalities in the vocational training, distribution of responsibilities working groups.

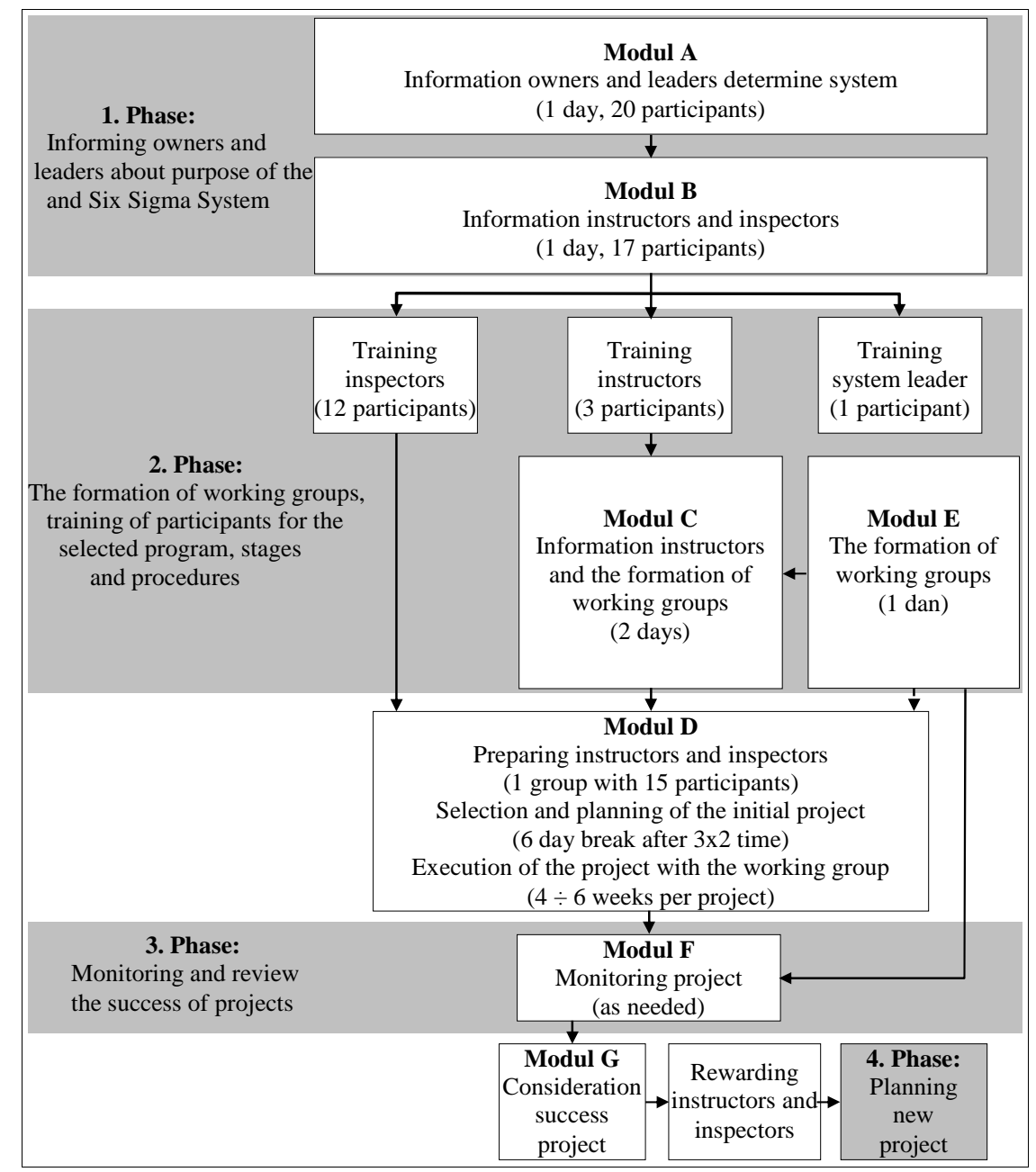

Figure 11: The scheme applying Six Sigma System

\section{Levels of staff of the Six Sigma System}

The staff of the Six Sigma System is classified into four levels: The highest level - Owners or directors (Champions); High level - Leader system (Mentor); Intermediate level managers - Leaders of working groups (Black belts); Basic level Instructors (Black Belts) and inspectors (Green belts). The owner and director (Champions) is at the highest level that defines organization's objectives and oversees the Six Sigma system. The leader of the system (Mentor) is at high level of management, at a separate workplace, and he is trained to conduct Six Sigma System, reeling and monitoring projects and selection of leaders of the working groups. The leaders of the working groups (Black Belt) are at the intermediate level of management and they are trained to conduct working groups. The instructors (Black Belt) for existing jobs are at the level of direct perpetrators and they are trained for interpretation and application of procedures, as well as inspectors (Green Belt), who are trained for using certain procedures.

The distribution of individuals responsibilities in Six Sigma System is accomplished according to the hierarchy: the owner (manager), the leader of the system and the leaders of the working groups depending on the number of projects and locations of organization (Popović, 1993). If the organization implemented only one project, then the responsibility is transferred from the personality of the owner (director) at the leader of a system, to the leader of the working group, instructors and inspectors. If the organization implemented a number of projects, it is the responsibility of the personality, the program Six Sigma System, according to the hierarchy of the owner (director) to the leader of the system and the 
leaders of the working groups. Figure 12. shows the scheme of distribution of responsibilities in 4 projects ( 2 projects at the first location, one project at second location, and one project at a remote location in the third organization.

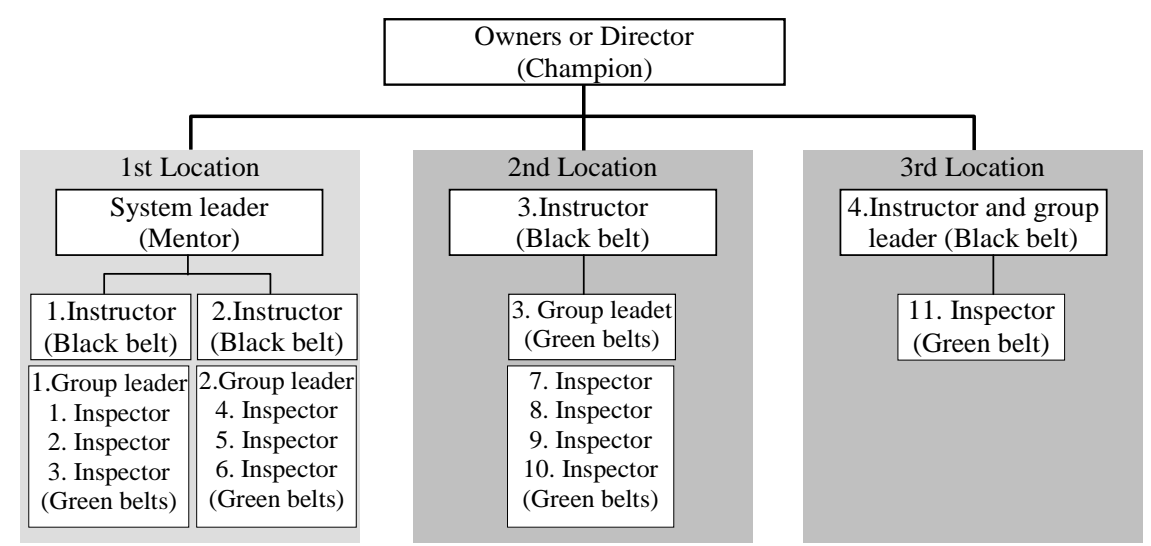

Figure 12: An example of distribution of responsibilities at three locations

\section{Staff training in Six Sigma System}

For implementation of Six Sigma System in organizations, it is necessary to qualify the required personnel at special seminars, where they gain qualifications of instructors (Black Belt) for advisory assistance and inspectors (Green Belt) for execution of projects of Six Sigma. An applied training plan of Six Sigma System at seminars in Belgrade is shown in Figure 13. Then, each participant at the seminar received a copy of required manuals and set tasks for the solution of independent solving approach with the possible assistance. Tasks can be independently solved using similar case in the resulting document and possible assistance.

After solving the tasks, the review and replenishment solutions are carried out while addressing special attention to working independently and understanding solutions with a written knowledge test. If the participant of the seminar successfully solves all the tasks with understanding he/she will receive a diploma of instructor (Black Belt), for specific application of Six Sigma System, or iff the participant of the seminar successfully solves half of the tasks with the understanding he/she receives a degree of inspectors (Green Belt), for a specific program of the Six Sigma System. The organization selects the required type of program, on the first level, considering its perceived vital problems. The seminar with voters required type of program, for: researching market demand for the results of the process (MFSS) management organization (LFSS), the design of the process (DFSS), implementation of the results of the process (PFSS) or serving of the results of the process (SFSS); they will appear immediately and the details of illustrative example of the solutions of the project of the selected programme. Then, division of manual and tasks with more explanation follows. Each participant receives seminar required manual for the selected programme and necessary number of tasks to be solved. Tasks can be independently solved using similar case in the resulting document and necessary assistance. The participant applies to computer with special software program Minitab (version 17), also using similar case in the obtained manual.

\section{CONCLUSIONS}

In Serbia, the applicable ISO 9000 family of standards has been developed since 1987 due to demonstration of the ability of suppliers. This allows only stabilization of the current level of quality but not increasing the quality that can be achieved only through better design and application of new materials and technologies. In America, Six Sigma System was created in 1986 (Motorola) to actually increase the level of quality and organization's profit by using modern computer technology, which allows the reduction of defects in the process up to the defects of 3.4 million realised results of the process. 


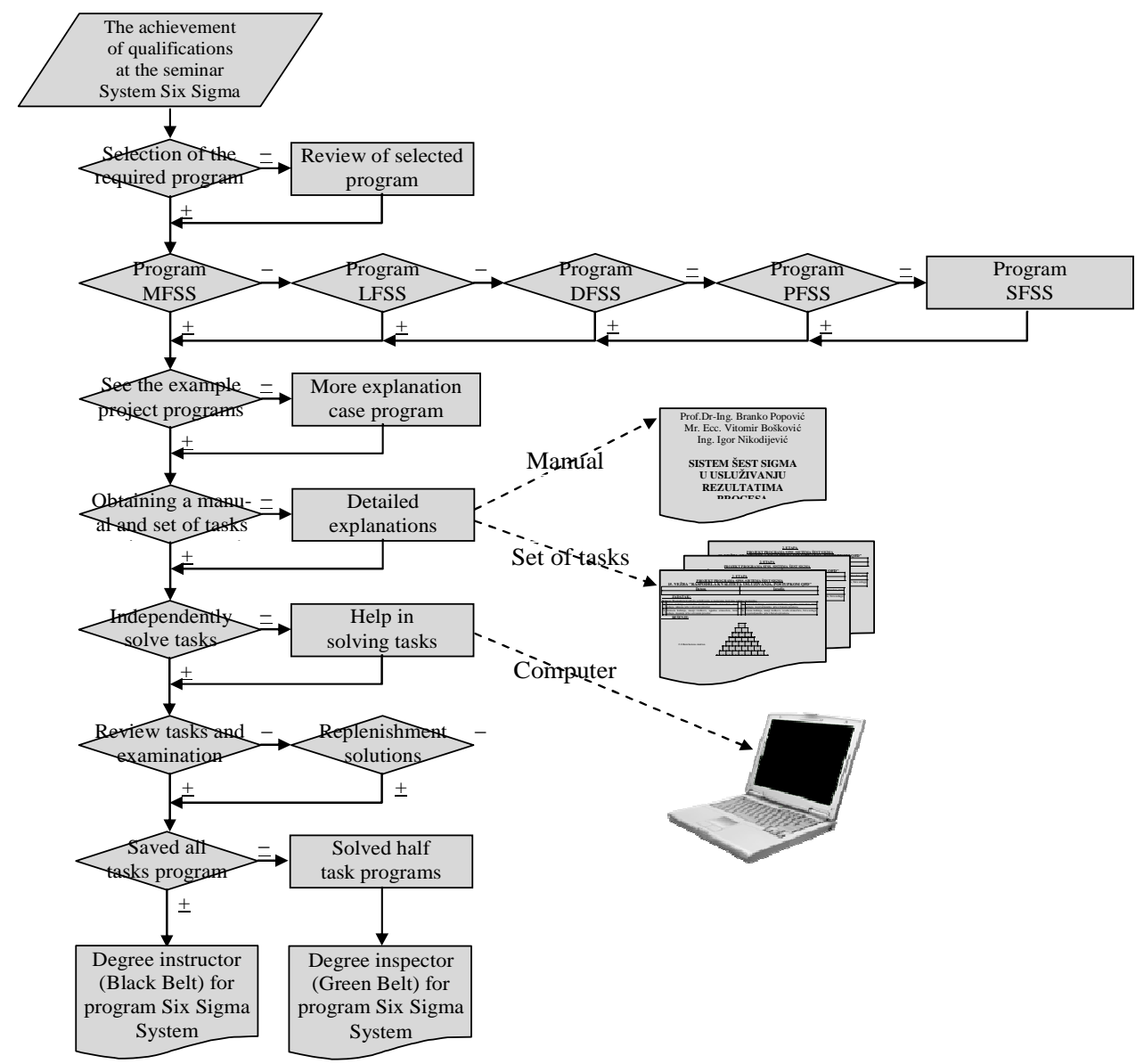

Figure 13: Plan training seminars Six Sigma System

This system is difficult to achieve in Serbia, so we have developed a special system of Six Sigma, which allows the use of a number of projects for the reduction of possible costs, shortening time rational, radical elimination of losses, significant increase of the quality of the process and organization's profit. The system uses alreadyemployed workers who are trained at special seminars for instructors (Black Belt) and inspectors (Green Belt) in the Six Sigma System. Training seminars include the use of prepared manuals and independently solved practical tasks, with the use of computer programs: Excel, RiskAmp, Minitab and Crystall Ball.

\section{ACKNOWLEDGEMENT}

This work was developed with several different business organizations, as well as by studying the existing opportunities to increase product quality in Serbia. The authors would like to thank: Vitomir Boskovic, Director of Quality Industry of Precision Mechanics and Igor Nikodijević CFO Industry of Precision Mechanics in Belgrade, Serbia.

\section{REFERENCES}

Ćoćkalo, D., Đorđević, D., Bešić, C., \& Bogetić, S., (2015). Unergraduate business student's attitudes towards CSR and competitiveness of Serbian economy. Journal of Engineering Management and Competitiveness (JEMC), 5(1), 12-20.

De Feo, J., \& Barnard, B. (2005). Juran Institute's Six Sigma Breakthrough and Beyond: Quality Performance Breakthrough Methods. New York: McGraw-Hill.

George, M., Rowlands, D., Price, M., \& Maxey, J. (2005). Lean Six Sigma Pocket Toolbook. New York: McGraw-Hill.

Harry, M., \& Schroeder, R. (2000). Six Sigma. New York: Doubleday.

Imai, M. (1979). Kaizen: The Key To Japan's Competitive Success. New York: McGraw-Hill.

Ishikawa, K. (1985). What is Total Quality Control? the Japanese Way. New York: Prentice Hall.

ISO. (2011). ISO 13053-1:2011 Quantitative methods in process improvement - Six Sigma - Part 1: DMAIC methodology: ISO - International Organization for Standardization.

ISO. (2011a). ISO 13053-2:2011 Quantitative methods in process improvement - Six Sigma - Part 2: Tools and techniques: ISO - International Organization for Standardization. 
ISO. (2012). ISO 7870-3:2012 Control charts - Part 3: Acceptance control charts: ISO - International Organization for Standardization.

ISO. (2015) ISO 9001:2015 Quality management systems - Requirements. ISO - International Organization for Standardization.

Juran J., Juran on quality by design, McMillan, New York (1992)

Kano, N. (1984), Attractive quality and must-be quality, The Journal of the Japanese Society for Quality Control, April, pp. 39-48

Милетич, Л., Попович, Б., Ничич, М. \& Вукович, М. (2015). Проект "Системы шести сигм" в контексте повышения качества в области маркетинга, ТРУДЫ МЕЖДУНАРОДНОГО СИМПОЗИУМА НАДЕЖНОСТЬ И КАЧЕСТВО (2), 232-235

Miletić, Lj. \& Ničić, M. (2016). Project of Implementation of Tools for Advanced Planning in Supply Chains Quality. ТРУДЬ МЕЖДУНАРОДНОГО СИМПОЗИУМА НАДЕЖНОСТЬ И КАЧЕСТВО (2), 288-293.

Miletić, Lj., Popović, B., \& Pavlović N. (2005). Organizaciona ponašanja. Novi Sad: Viša poslovna škola.

Oakland, J. S. (2003). TQM (3 ed.). Jordan Hill, Oxford: Linacre House.

Ohno, T. (1988). Toyota production sistem. Stamford: Productivity Press.

Popović, B. (1990). Proizvodne tehnologije. Beograd: Naučna knjiga.

Popović, B. (1993). Ulazna kontrola u sistemu kvaliteta -Incoming-material control. Beograd: Nauka.

Popović, B. (2016). Sistem šest sigma u rukovođenju organizacijom - Leadership for Six Sigma. Beograd: Akademska misao.

Popović, B. (2016a). Sistem šest sigma u povišenju profita - System Six Sigma. Beograd: Akademska misao.

Popović, B., \& Bošković, V. (2011). Korišćeni kvalitet proizvoda. Beograd: Akademska misao.

Popović, B., \& Ivanović, G. (2011). Sistem šest sigma u projektovanju rezultata procesa - Design for six sigma. Beograd: Mašinski fakultet.
Popović, B., \& Klarin, M. (2002). Procesna kontrola $u$ Sistemu upravljanja kvalitetom-Proccess Control. Beograd: Mašinski fakultet.

Popović, B., \& Klarin, M. (2003). Projektovani kvalitet proizvoda - Quality of Design. Beograd: Mašinski fakultet.

Popović, B., \& Klarin, M. (2007). Realizovani kvalitet proizvoda - Quality of conformance. Beograd: Mašinski fakultet.

Popović, B., \& Miletić, L. (2015). Kontrolisanje ukupnog kvaliteta - Overal Quality System. Paper presented at the 42. Nacionalna konferencija o kvalitetu, Kragujevac.

Popović, B., \& Nikodijević, I. (2015). Sistem šest sigma u istraživanju tržišnih potreba - Marketing for Six Sigma. Beograd: Akademska misao.

Popović, B., \& Todorović, Z. (1998). Obezbeđenje kvaliteta (Quality Assusurance). Beograd: Nauka.

Popović, B., \& Todorović, Z. (2000). Izlazna kontrola u sistemu kvaliteta -Product control. Beograd: Nauka.

Popović, B., Bošković, V., \& Nikodijević, I. (2014). Sistem šest sigma u usluživanju rezultatima procesa - Servicing for Six Sigma. Beograd: Akademska misao.

Popović, B., Klarin, M., \& Miletić, Lj. (2003). Upravljanje proizvodnjom i usluživanjem Operations Management. Beograd: Mašinski fakultet.

Popović, B., Klarin, M., \& Veljković, Z. (2008). Sistem šest sigma u realizovanju rezultata procesa Processing for Six Sigma. Beograd: Mašinski fakultet.

Pyzdek, T. (2003). The Six Sigma Handbook. New York: McGraw-Hill

Quinn, R.E. (1996). Becoming a Master Manager. New York: John Wiley and Sons.

Stamatis, D.H. (2003). Six Sigma and Beyond. London: St. Lucie Press.

Summers, D. (2000). Quality. New Jersey: Prentice Hall.

Taguchi, G. (1986). Introduction to quality engineering. Tokio: Asian Productivity Association.

Truscott, W. (2003). Six Sigma: Continual Improvement for Businesses. Oxford: Butterworth-Heinemann.

\title{
ŠEST SIGMA I SISTEM ŠEST SIGMA U FUNKCIJI POVEĆANJA KVALITETA I PROFITA
}

\begin{abstract}
Kvalitet predstavlja stepen u kome skup stalnih karakteristika ispunjava zadate, postavljene ili ugovorene zahteve za rezultatom procesa (poluproizvoda, proizvoda, dokumentacije, usluga). U Americi, s obzirom da oni imaju sasvim drugačiji pristup održavanju nivoa kvaliteta procesa. se smatra da kvalitet uvek određuje korisnik, a ne isporučilac, pa se kvalitet posmatra preko troškova. Da bi se u Srbiji pokazala sposobnost isporučioca, primenjuju se standardi familije ISO 9000 koji omogućavaju samo da se stabilizuje postojeći nivo kvaliteta, ali ne i da se poveća nivo kvaliteta rezultata procesa, koji se može ostvariti primenom novih materijala i tehnologija. Primena Šest Sugma, predstavlja drugačiji pristup, koji omogućava realno povećaćanje nivo kvaliteta i profita organizacije i korišćenjem savremene računarske tehnologije smanjenje grešaka
\end{abstract}


u procesu, sve do 3,4 greške na milion realizovanih rezultata procesa. S obzirom da je u Srbiji ovo teško ostvarljivo, autori su razvili Sistem Šest Sigma, koji je prilagođen našim uslovima i omogućava realizaciju niza projekata za smanjenje mogućih troškova i skraćenje vremena procesa, radikalno otklanjanje gubitaka, poboljšanje kvaliteta procesa i povećanje profita organizacije.

Ključne reči: Upravljanje kvalitetom, Šest Sigma, Sistem Šest Sigma. 